DOI: $10.12731 / 2070-7568-2021-10-1-82-105$ УДК 338.43

\title{
СОВРЕМЕННОЕ СОСТОЯНИЕ МЯСНОЙ ПРОМЫШЛЕННОСТИ В УСЛОВИЯХ ТЕХНОЛОГИЧЕСКОГО РАЗВИТИЯ АГРАРНОГО СЕКТОРА КАЗАХСТАНА
}

\author{
Сапарова Г.К., Касенова А.Ж., \\ Насырова А.М., Сулейманов Р.Э.
}

Наџиональная программа «Развитие мясного животноводства на 2018-2027 г2.» предусматривает тенденцию развития конкурентоспособности мясоперерабатьвающих предприятий на технологический рост, где инновачии обязаны быть комплексными, включающими все функциональные области, соприкасаюшиеся с деятельностью предприятий. Инновационное развитие отраслей АПК Казахстана, в том числе животноводства является важным фактором обеспечения продовольственной безопасности государства. Главный признак благосостояния государства - это рост потребления аграрной продукиии, в том числе мяса и мясопродуктов на душу населения. В связи с этим необходимо уделить внимание качественному развитию животноводства и росту его продуктивности. К сожалению, мясомолочная продукция Казахстана недостаточно конкурентоспособна, в связи с технологическим отставанием сельскохозяйственных и перерабатывающих предприятий, изношенностью оборудования, отсутствием создания инновационных разработок экологической продукции.

В статье рассмотрено текущее состояние мясной промышленности Республики Казахстан и конкретизированы этапы ее развития. На основе анализа статистических данных осуществлена оценка динамики производства, импорта, экспорта мяса и мясных продуктов. Предложены рекомендации по повышению конкурентоспособности продукции и освещены перспективы развития мясоперерабатывающеей отрасли Республики Казахстан в современных условиях. 
Актуальность научной статьи обоснована тем, что мясная промыпиленность является стратегической отраслью аграрного сектора экономики Казахстана, которая, в свою очередь, считается составной частью системы продовольственной безопасности. В связи с этим необходимо определить основные проблемы, сдерживающие развитие отечественных производителеймясной продукиии, несовершенства законодательной сферы, не отлаженности рыночной инфраструктуры.

Индустриальное развитие экономики АПК страны, в том числе мясной отрасли требует новых подходов государственного регулирования и разработки мер государственной поддержки данной сферы. Так возникает необходимость выполнения научных исследований по определенной теме, с учетом возникнувиих экономических ситуаций развития мясной промыпленности. Важность определения задач, относящиихя к государственному регулированию экономики Казахстана в сфере мясной промышленности, а также недостаточная изученность некоторых теоретических и практических аспектов развития аграрного сектора, в том числе жсивотноводства определили спектр темы и потребность глубоких исследований этой отрасли.

Целью исследования является проведение анализа развития мясной промышленности Республики Казахстан, выявление главных причин, сдерживающих развитие мясоперерабатывающей промышленности и определение направлений, которые будут благоприятствовать повышению конкурентоспособности производимой продукиии, вытеснению импорта и росту экспорта.

Обзор литературы. Актуальность проблемы, побуждает отечественных ученых к исследованию развития животноводства в современных условиях. В экономической литературе, широко изучаются экономические взаимоотношения между государством и хозяйствующими субъектами, механизмы их регулирования. Вопросам разработки принципиальных положений, концепций, механизмов, созданию форм государственной поддержки, конкурентоспособности мясной промышленности посвящены работы как отечественных, так и зарубежных ученых C.E. Staley, V. Ваупоv, М. Трейси, А.К. Жумагулова, Г.Б. Саханова, Г.А. Калиев, А.Б. Молдамев, Г.К. Сапарова и многих 
других. Исследование данного вопроса особенно актуально в связи с решением проблемы роста продовольственного обеспечения населения экологически чистой, безопасной мясной продукцией, что требует развития более совершенных технологий, роста предпринимательской деятельности предприятий крупного, среднего и малого бизнеса в аграрном секторе.

Методологической основой исследования являются основные положения экономической теории, современные теории конкурентных отношений, а также экономические обзоры и отчеты исполнительных органов Республики Казахстан. В ходе исследования были использованы методы системного анализа, экономико-статистических, абсолютных и средних величин и др.

Результаты: на основе системного анализа с использованием экономико-статистических данных определены приоритетные направления повышения конкурентоспособности мясной промышленности страны.

Область применения результатов: проведеннье исследования могут использоваться в решении проблемы роста продовольственного обеспечения населения экологически чистой, безопасной мясной продукиией, что требует развития более совершенных технологий, роста предпринимательской деятельности предприятий крупного, среднего и малого бизнеса в аграрном секторе.

Ключевые слова: мясная промышленность; мясная продукиия; технологическое развитие; качество продукции; коммерииализация; государственные программы; конкурентоспособность; импорт; экспорт; внутренний валовый продукт.

\section{THE CURRENT STATE OF THE MEAT \\ INDUSTRY IN THE TECHNOLOGICAL DEVELOPMENT OF THE AGRARIAN SECTOR OF KAZAKHSTAN}

\section{Saparova G.K., Kassenova A.Zh., Nassyrova A.M., Suleimanov R.E.}

The roadmap of development of competitiveness of meat processing enterprises provides their tendency to technological growth, where in- 
novations must be cumulative, including all functional areas, contacting with the activity of enterprises. Among the main tendencies of development of agroindustrial complex of Kazakhstan and inseparable part of strategic security of the state is livestock breeding. The main signs of state well-being is consumption of agrarian production increase, including meat and meat products per capita. It is necessary to pay attention to high quality development of cattle breeding and growth of its productivity. Unfortunately, meat and dairy products of Kazakhstan are not competitive enough, due to technological backwardness of producing and processing enterprises, depreciation of equipment, and lack of creation of innovative developments of ecological products.

The article considers the current state of the meat industry of the Republic of Kazakhstan and specifies the stages of its development. On the basis of the analysis of statistical data the dynamics of production, imports, exports of meat and meat products has been evaluated. Recommendations for improving the competitiveness of products and highlights the prospects for the development of the meat processing industry of the Republic of Kazakhstan in modern conditions.

The relevance of the scientific article is justified by the fact that the meat industry is a strategic sector of the agrarian sector of the economy of Kazakhstan, which, in turn, is considered a part of the food security system. In this connection, it is necessary to define the basic problems constraining development of domestic manufacturers of meat production, imperfections of the legislative sphere, not debugging of a market infrastructure.

The radical changes arising in economy of the country for meat industry demand development of modern methods in the decision of problems of the state regulation and development of measures of the state support of the given sphere. So there is a necessity of performance of scientific researches on the certain theme, taking into account the arisen economic situations of development of meat industry. Importance of definition of the problems concerning state regulation of economy of Kazakhstan in sphere of meat industry, and also insufficient studying of some theoretical and practical aspects of development of agrarian sec- 
tor, including animal industries have defined a spectrum of a theme and necessity of deep researches of this branch.

The purpose of the study is to analyze the development of the meat industry of the Republic of Kazakhstan, identifying the main reasons that constrain the development of the meat processing industry and identifying areas that will enhance the competitiveness of manufactured products, displacement of imports and export growth.

Literature review. The urgency of the problem encourages domestic scientists to study the development of animal husbandry in modern conditions. Economic relations between the state and economic entities and the mechanisms of their regulation are widely studied in the economic literature. The works of both domestic and foreign scientists C.E. Staley, V. Baynov, M. Tracy, A.K. Zhumagulov, G.B. Sakhanov, G.A. Kaliev, and A.B. Kaliev, A. B. Moldashev, G.K. Saparov and many others are devoted to the development of the main provisions, concepts, mechanisms, the creation of forms of state support and the competitiveness of the meat industry. The study of this issue is particularly relevant in connection with the solution of the problem of increasing the food supply of the population with environmentally friendly, safe meat products, which requires the development of more advanced technologies, the growth of entrepreneurial activity on a large scale, medium and small businesses in the agricultural sector.

The methodological basis of the study are the main provisions of economic theory, modern theories of competitive relations, as well as economic surveys and reports of executive bodies of the Republic of Kazakhstan. In the course of the study the methods of system analysis, economic and statistical, absolute and average values, etc. were used.

Results: on the basis of system analysis using economic and statistical data priority areas to improve the competitiveness of the meat industry of the country are defined.

Scope of the results: the conducted research can be used in solving the problem of growth of food supply of the population with ecologically clean, safe meat products, which requires the development of more advanced technologies, growth of entrepreneurial activity of large, medium and small businesses in the agrarian sector. 
Keywords: meat industry; meat products; technological development; product quality; commercialization; government programs; competitiveness; import; export; gross domestic product.

\section{Введение}

Сегодня Казахстан стремится достигнуть уровня производства аграрной продукции доперестроечного периода и перейти к его устойчивому росту. Переход Казахстана к рыночным отношениям в 1990-ые годы и их развитие в последующий период характеризовался высокой инфляцией, снижением жизненного уровня населения, дестабилизацией экономики, неблагоприятным соотношением цен на сельскохозяйственную и промышленную продукцию, спадом всех производственных и обслуживающих предприятий как в целом народнохозяйственном комплексе, так и в аграрном секторе. Сложившийся диспаритет цен привёл к снижению использования минеральных удобрений в 2000 году по сравнению с 1990 г. в 59 раз, а органических удобрений - в 128 раз, к сокращению парка тракторов в 5 раз, доильных установок и агрегатов в 17 раз, зерноуборочных комбайнов в 4 раза [12]. За период 1991-2000 гг. произошло снижение производства мяса более чем в 2 раза, молока $-1,5$ раза, яиц $-2,4$ раза и т. д. [11].

История преподносит нам редкую возможность сравнить, осмыслить произошедшие реформы в аграрном секторе с учетом влияния социально-психологических, организационно-экономических, национальных, экологических факторов и внедрять новые, не подвергая народ новым непродуманным экспериментам.

Мясная промышленность считается одной из основных отраслей экономики в сфере материального производства, и от её развития зависит полноценное питание населения такими продуктами как мясо и мясные изделия, молочная продукция. В Казахстане производство и потребление мяса и мясных продуктов связано с этническими особенностями питания жителей.

Увеличение потребительского спроса на мясо и мясную продукцию, слабая инвестиционная активность и высокие показатели зависимости аграрного рынка от импорта определяют потребность 
развития мясной отрасли. За прошедший период доля мясной промышленности в ВВП Казахстана составило 2,3\%, а в объёме валового производства сельского хозяйства составило 45\% (таблица 1).

Таблицуа 1.

Валовое внутреннее производство за 2017-2019 гг. млрд. тенге

\begin{tabular}{|l|l|l|l|l|c|}
\hline \multirow{2}{*}{ Показатели } & \multirow{2}{*}{2017 г. } & \multirow{2}{*}{$\mathbf{2 0 1 8}$ г. } & \multirow{2}{*}{$\mathbf{2 0 1 9}$ г. } & $\mathbf{2 0 1 9}$ г. / 2017 г. \\
\cline { 5 - 7 } & & & & $+/-$ & $\mathbf{\%}$ \\
\hline ВВП всего & 54378,9 & 61819,5 & 69532,6 & 15153,7 & 127,9 \\
\hline ВВП сельского хозяйства & 4092,3 & 4497,6 & 5177,9 & 1085,6 & 126,5 \\
\hline в т. ч.: животноводство & 1810,9 & 2050,5 & 2319,5 & 508,6 & 128,1 \\
\hline
\end{tabular}

В таблице видно, что ВВП сельского хозяйства увеличился в 2019 году по сравнению с 2017 годом более чем на 26,5\% и составил 5 177,9 млрд. тенге. В структуре сельского хозяйства ВВП животноводства показал рост на 28,1\%, составил 2 319,5 млрд. тенге.

Специфичность изготовления мяса и мясопродуктов непосредственно взаимосвязана с особенностями отрасли животноводства. Экономический рост и увеличение конкурентоспособности отечественных товаропроизводителей на мясном рынке связано с форсированным развитием всех видов скота.

Главная цель развития мясной промышленности Казахстана - это рост уровня обеспеченности жителей страны мясом и мясной продукцией отечественного производства в соответствии с рациональными нормами потребления [5]. Рациональные нормы потребления представляют собой сбалансированный набор продуктов с учетом традиций питания населения.

Существует экономическая и физическая доступность продовольствия. К экономической относится покупка продуктов по существующим ценам в объёме и ассортименте в соответствии с уровнем доходов населения. К физической доступности относится охват потребителей товаропроводящей инфраструктурой $[9,23]$.

По статистическим данным 2019 года государство обеспечило население Казахстана всеми видами мяса и мясных продуктов на уровне 78,3 кг на душу населения, при этом доля импорта состави- 
ла 19,2\%. В 2017 году обеспечение было на уровне 73,6 кг на душу населения, и доля импорта достигала 20,3\% (рисунок 1).

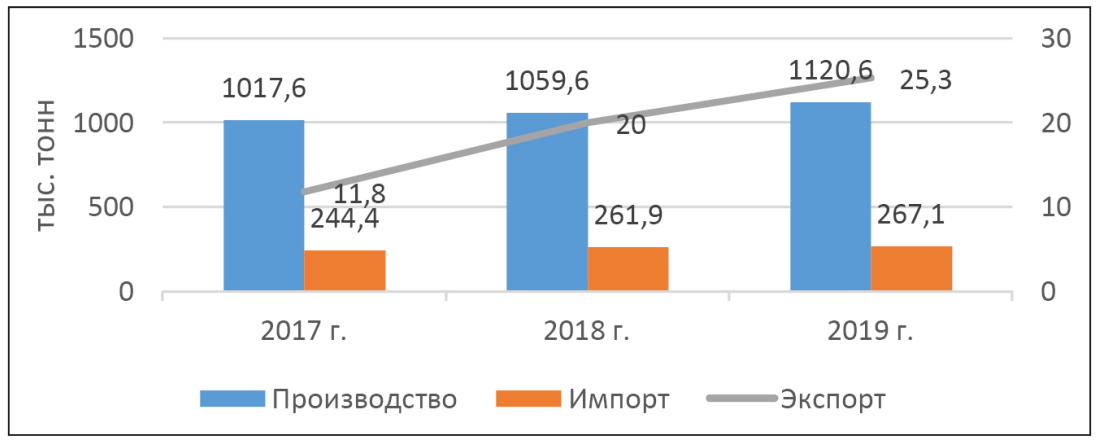

Рис. 1. Мясо и мясопродукты в тыс. тонн

Примечание: составлено авторами согласно источнику [13]

Так, на данный момент объём производства мяса и мясопродуктов практически достиг годовой рациональной нормы потребления и составляет 78,4 кг на душу населения [18]. При этом физиологическая норма потребления мяса и мясопродуктов в среднем 84 кг на душу населения.

В принятых мировых нормативах по обеспечению продовольственной безопасности, считается, что привозимая в страну импортная продовольственная продукция не должна превышать $15 \%$ в общем объёме его потребления [7]. На сегодняшний день наблюдается рост потребительского спроса на мясо и мясопродукты и в развитии мясной отрасли аграрного сектора показатели импорта составляют свыше 19\%, что превышает порог безопасности.

Для обеспечения потребления мяса и мясопродуктов в соответствии с физиологической нормой на душу населения надо полностью изменить всю сырьевую базу, порядок поставки, убой скота, начальную переработку мясного сырья и создать приемлемую систему производства мяса и мясопродуктов.

Объемы производства скота и птицы на убой в живой массе за 2017-2019 гг. приведены в таблице 2. 
Таблицуа 2.

Производство скота и птицы на убой за 2017-2019 гг., в живой массе тыс. тонн

\begin{tabular}{|c|c|c|c|c|c|}
\hline \multirow{2}{*}{ Объем производства } & \multirow{2}{*}{2017 г. } & \multirow{2}{*}{2018 г. } & \multirow{2}{*}{2019 г. } & \multicolumn{2}{|c|}{$2019 / 2017$} \\
\hline & & & & $+1-$ & $\%$ \\
\hline $\begin{array}{l}\text { Скот и птица } \\
\text { в том числе: }\end{array}$ & 1794,4 & 1871,9 & 1975,0 & 180,6 & 110,1 \\
\hline крупнорогатый скот & 853,5 & 906,2 & 960,3 & 106,8 & 112,5 \\
\hline овцы и козы & 345,9 & 343,5 & 343,9 & $-2,0$ & 99,4 \\
\hline лошади & 226,7 & 244,3 & 255,1 & 28,4 & 112,5 \\
\hline свиньи & 130,9 & 122,8 & 123,0 & $-7,9$ & 94,0 \\
\hline верблюды & 12,6 & 12,7 & 13,0 & 0,4 & 103,2 \\
\hline птицы & 224,8 & 242,4 & 279,7 & 54,9 & 124,4 \\
\hline
\end{tabular}

В целом объёмы производства скота и птицы на убой за периоды 2017-2019 гг. выросли на 180,6 тыс. тонн, то есть прирост 10,1\%. Вместе с тем приход на убой овец и коз за этот же период уменьшился на 2 тыс. тонн, недовыполнение $0,6 \%$ к 2017 г., поставки свиней в живом весе сократились на 7,9 тыс. тонн, недовыполнение 6\%. Совокупный рост приход получился из-за повышения объемов производства крупного рогатого скота на $12,5 \%$ и лошадей на $12,5 \%$ соответственно. По данным таблицы 2 получается, что общий рост объемов производства скота и птицы на убой в значительной степени достигнут благодаря повышению производства птицы, что составило $24,4 \%$.

Производство скота и птицы на убой в разрезе сельскохозяйственных предприятий, хозяйств населения и крестьянских хозяйств показаны в таблице 3.

Таблицуа 3.

Производство скота и птицы на убой по категориям хозяйств за 2017-2019 гг., в живой массе тыс. тонн

\begin{tabular}{|c|c|c|c|c|c|}
\hline \multirow{2}{*}{ Категория хозяйств } & \multirow{2}{*}{2017 г. } & \multirow{2}{*}{2018 г. } & \multirow{2}{*}{2019 г. } & \multicolumn{2}{|c|}{$2019 / 2017$} \\
\hline & & & & $+1-$ & $\%$ \\
\hline $\begin{array}{l}\text { Всего, } \\
\text { в том числе: }\end{array}$ & 1794,4 & 1871,9 & 1975,0 & 180,6 & 110,1 \\
\hline сельхозпредприятия & 353,4 & 385,3 & 446,9 & 93,5 & 126,5 \\
\hline $\begin{array}{l}\text { крестьянские } \\
\text { (фермерские) хозяйства }\end{array}$ & 366,9 & 393,0 & 413,9 & 47 & 112,8 \\
\hline хозяйства населения & 1074,1 & 1093,6 & 1114,2 & 40,1 & 103,7 \\
\hline
\end{tabular}


По данным таблицы 3 видно, что основное обеспечение скота и птицы на убой по категориям хозяйств приходится на хозяйства населения. При общем показателе производства скота и птицы на убой в живой массе 1975 тыс. тонн на хозяйства населения приходится 1 114,2 тыс. тонн или 56,4\%.

Показатели производства скота и птицы в убойной массе за 2017 2019 гг. приведены в таблице 4.

Таблицуа 4.

Производство скота и птицы за 2017-2019 гг., в убойной массе тыс. тонн

\begin{tabular}{|l|l|l|l|l|l|}
\hline \multirow{2}{*}{ Объем производства } & \multirow{2}{*}{$\mathbf{2 0 1 7}$ г. } & \multirow{2}{*}{$\mathbf{2 0 1 8}$ г. } & \multirow{2019}{*}{ г. } & \multicolumn{2}{|c|}{$\mathbf{2 0 1 9 / 2 0 1 7}$} \\
\cline { 5 - 7 } & & & & $+/-$ & $\mathbf{9}$ \\
\hline $\begin{array}{l}\text { Скот и птица, } \\
\text { в том числе: }\end{array}$ & 1017,6 & 1059,6 & 1120,6 & 103,0 & 110,1 \\
\hline крупнорогатый скот & 450,6 & 477,5 & 501,3 & 50,7 & 111,3 \\
\hline овцы и козы & 171,4 & 170,6 & 171,4 & 0,0 & 100,0 \\
\hline лошади & 117,5 & 126,5 & 132,0 & 14,5 & 112,3 \\
\hline свиньи & 91,9 & 86,1 & 86,4 & $-5,5$ & 94,0 \\
\hline верблюды & 6,6 & 6,7 & 6,8 & 0,2 & 103,0 \\
\hline птицы & 179,6 & 192,2 & 222,7 & 43,1 & 123,9 \\
\hline Примечание: составлено авторами согласно источнику [13] \\
\hline
\end{tabular}

За 2017-2019 гг. производство скота и птицы в убойной массе выросло в 1,1 раза, больше всего из-за роста объемов поступления птицы на 23,9\%, лошадей на $13,3 \%$ и крупно рогатого скота на $11,3 \%$ соответственно.

Анализ поставок скота и птицы на убой различными хозяйствами за аналогичный период показывает, что главный прирост обеспечен сельскохозяйственными предприятиями, что составляет $-24,6 \%$. Вместе с тем, поставки от хозяйств населения увеличились на $3 \%$, от фермерских хозяйств на 12,3\% (таблица 5).

В большинстве стран наблюдается, что во всём объеме производства мяса, доля крупных хозяйств занимает большую часть. Потому что рентабельность разведения скота и птицы в сельскохозяйственных предприятиях промышленного типа гораздо выше, нежели в малых хозяйствах. 
Таблииа 5 .

Производство скота и птицы по категориям хозяйств за 2017-2019 гг., в убойной массе тыс. тонн

\begin{tabular}{|c|c|c|c|c|c|}
\hline \multirow{2}{*}{ Категория хозяйств } & \multirow{2}{*}{2017 г. } & \multirow{2}{*}{2018 г. } & \multirow{2}{*}{2019 г. } & \multicolumn{2}{|c|}{$2019 / 2017$} \\
\hline & & & & $+/-$ & $\%$ \\
\hline $\begin{array}{l}\text { Всего, } \\
\text { в том числе: }\end{array}$ & 1017,6 & 1059,6 & 1120,6 & 103,0 & 110,1 \\
\hline сельхозпредприятия & 252,8 & 271,6 & 315,1 & 62,3 & 124,6 \\
\hline $\begin{array}{l}\text { крестьянские } \\
\text { (фермерские) хозяйства }\end{array}$ & 191,5 & 204,8 & 215,1 & 23,6 & 112,3 \\
\hline хозяйства населения & 573,3 & 583,2 & 590,4 & 17,1 & 102,9 \\
\hline
\end{tabular}

Данные численности поголовья во всех хозяйствах считаются в числе главных показателей, определяющие объёмы сбыта скота и птицы на убой (таблица 6).

Таблицуа 6.

Численность скота и птицы во всех категориях хозяйств тыс. голов

\begin{tabular}{|l|l|l|l|l|l|}
\hline \multirow{2}{*}{ Наименования } & \multirow{2}{*}{$\mathbf{2 0 1 7}$ г. } & \multirow{2}{*}{$\mathbf{2 0 1 8}$ г. } & \multirow{2}{*}{$\mathbf{2 0 1 9}$ г. } & \multicolumn{2}{|c|}{$\mathbf{2 0 1 9} / \mathbf{2 0 1 7}$} \\
\cline { 5 - 7 } & & & & $+/-$ & \% \\
\hline крупнорогатый скот & 6764,2 & 7150,9 & 7436,4 & 672,2 & 109,9 \\
\hline овцы и козы & 18329,0 & 18699,1 & 19155,7 & 826,7 & 104,5 \\
\hline лошади & 2415,7 & 2646,5 & 2852,3 & 436,6 & 118,1 \\
\hline свиньи & 815,1 & 798,7 & 813,3 & $-1,8$ & 99,8 \\
\hline птицы & 39913,5 & 44377,9 & 45041,4 & 5127,9 & 112,8 \\
\hline верблюды & 193,1 & 207,6 & 216,4 & 23,3 & 112,1 \\
\hline Примечание: составлено авторами согласно источнику [13] \\
\hline
\end{tabular}

За 2019 год в стране численность крупного рогатого скота по отношению к 2017 году повысилась на 10\%. Также за рассматриваемый период увеличились численности овец и коз на 4,5\%, лошадей - на более чем $18 \%$, верблюдов на $12,1 \%$. Отметился прирост птиц - на $12,8 \%$, а количество свиней снизились на $0,2 \%$, что связано с возникающими периодическими спадами.

Для отрасли животноводства характерно постепенное увеличение показателей на протяжении всего исследуемого промежутка времени, что связано с ростом цены на продукцию животноводства.

Для успешного роста предприятий, занимающихся животноводством, нужно, чтобы отрасль приносила прибыль. Для определения 
производства более выгодных видов продуктов животноводства осуществляется экономический анализ по натуральным и ценовым признакам. Показатели производства некоторых видов продукции животноводства за 2017-2019 гг. предоставлены в таблице 7.

Таблицьа 7.

Производство отдельных видов продукции животноводства

\begin{tabular}{|c|c|c|c|c|c|c|}
\hline \multirow{2}{*}{ Наименования } & \multirow{2}{*}{ Ед. изм. } & \multirow{2}{*}{2017 г. } & \multirow{2}{*}{2018 г. } & \multirow{2}{*}{2019 г. } & \multicolumn{2}{|c|}{2019 / 2017 гг. } \\
\hline & & & & & $+/-$ & $\%$ \\
\hline Молоко & тыс. тонн & 5503,4 & 5686,2 & 5864,9 & 361,5 & 106,6 \\
\hline Яйца & млн. штук & 5103,0 & 5591,4 & 5531,4 & 428,4 & 108,4 \\
\hline Шерсть & тыс. тонн & 39,0 & 39,2 & 39,5 & 0,5 & 101,3 \\
\hline
\end{tabular}

Расчеты на основе данных таблицы 7 показывают рост производства молока на $6,6 \%$, яиц $-8,4 \%$, шерсть $-1,3 \%$.

Из произведённого статистического анализа сделаны следующие выводы:

- в сфере сельского хозяйства животноводство является одной из важных отраслей, производящих главные продукты питания и сырьё для иных областей экономики государства;

- развитие животноводческой отрасли ограничено ростом поголовья скота, жизненный цикл которого имеет длительный период, а также тем, что для производства готового продукта требуются сложные технологические процессы;

- производство продукции животноводства довольно энергозатратное, до 20 раз выше, чем в растениеводстве;

- для развития животноводческой отрасли нужно, чтобы экономика государства, в том числе сельского хозяйства были на достаточно высоком уровне и был высокий спрос на данную продукцию;

- в современных условиях должны получать развитие все разновидности агроформирований [8], но в первую очередь крупные предприятия [3], так как они имеют большие финансовые возможности внедрять новые технологии, а потому обладают более высокой конкурентоспособностью. 
Следует согласиться с авторами о необходимости создания современных предприятий полного цикла по принципу «от поля до прилавка», что позволит повысить их прибыльность почти в 3 раза, за счет интегрированного использования сельскохозяйственного сырья [4].

Рост сырьевой базы и экспорт переработанной сельхозпродукции является главной задачей «Плана нации - 100 шагов по реализации пяти институциональных реформ» [17]. Так, программа мясного животноводства по малым и средним хозяйствам начала реализовываться со второго полугодия 2018 года. Вместе с тем, запустили особый льготный кредитный продукт «Сыбаға», в пределах которого прокредитовали более 600 хозяйств на покупку 56 тысяч голов маточного поголовья крупного рогатого скота в общей сумме более чем 33 млрд. тенге. По данным компаний, в пределах программы «Сыбаға мелкого рогатого скота» прокредитовали 468 хозяйств на закуп 165 тыс. голов овец в сумме 5 млрд. тенге. По результатам 2019 года профинансирован закуп 130 тысяч голов крупного рогатого скота, более 200 тысяч голов мелкого рогатого скота и 12 тысяч голов лошадей. А на основании выданных ветеринарных сертификатов итоги мониторинга экспорта всего мяса составил более 33 тысяч тонн, в том числе говядины около 20 тысяч тонн [15].

В 2019 году отдельные регионы при поддержке государства добились существенных результатов в производстве мясных продукций. В Акмолинской области работает компания «Айтас»- самая крупная в Центральной Азии бройлерная птицефабрика мощностью в 60 тыс. тонн мяса птицы в год. По проекту откорма крупного рогатого скота на принципе давальческой программы «Аманат» на 13 главных откормплощадках определены на откорм 15 тысяч голов крупно рогатого скота. В процессе исполнения инвестиционного проекта с холдингом Cremonini отстроен сверхсовременный комплекс, где планируется перерабатывать до 180 тыс. голов крупно рогатого скота в год. К тому же, в столице Казахстана г. Нур-Султан началось строительство мясоперерабатывающего завода, с установкой новейших европейских оборудований. Технологическим участником программы является лидер китайского рынка компания GrandFarm, 
что позволит упростить экспорт в Китай. Вместе с акиматом восточно-казахстанской области компания из Австралии CedarMeats в Аягозе начали строительство завода по мясопереработке с мощностью 1,4 тыс. голов мелко рогатого скота в смену [14].

Экспортировать мясо для отечественных компаний выгодно. Так, например, в отчетном году только из-за экспорта говядины производители товаров получили 27 млрд. тенге [22].

В Казахстане есть 20 главных предприятий по экспорту говядины. Основные из них: ТОО «Кайыпата» (Туркестанская обл.), ТОО «Актеп» (Актюбинская обл.), ТОО «Кублей» (Западно-Казахстанская обл.), ТОО «Терра» (Костанайская обл.). Каждая из этих предприятий в 2018 году экспортировала свыше 2000 тонн говядины. Компании-экспортеры взаимодействуют с объединёнными крестьянскими хозяйствами регионов. В целом в программах мясного животноводства участвуют свыше 19 тысяч крестьянских хозяйств. Благодаря такому сотрудничеству крупных предприятий и крестьянских хозяйств мелькие сельхоз производители получают доступ к экспортному рынку [6]. Следует отметить, что повысился экспорт мясной продукции: в Иран - в 5,5 раза, в Узбекистан почти в 20 раз $(19,6)$, в Армению - в 17,4 раза, в Россию - в 2,1 раза [19-21].

Экспорт живого скота выгоден тем, что помимо мяса реализуются и субпродукты, шкуры, кости и т.д. Отечественная продукция дешевле, чем в странах, в которые экспортируется продукция. Цена на живой скот выросла с 450 до 700-800 тенге за последние 3 года, что благоприятно влияет на доходы фермеров.

Для того, чтобы добавленная стоимость оставалась в стране, и фермеры получали максимум от продажи животных, необходимо ввести запрет на забой скота во дворах. Промышленный убой составляет сегодня лишь 10\% и только от этого отрасль теряет около 100 млрд. ежегодно. Необходимо стимулирование фермеров и владельцев личных подсобных хозяйств к убою скота на мясокомбинатах, увеличить строительство крупных мясокомбинатов с целью повышения закупочных цен и организации экспорта переработанной продукции, а также всегда оставлять альтернативу по экспорту 
живого скота, что позволит формировать рыночные справедливые цены от фермеров.

Тем не менее, невзирая на устойчивость и определенный рост своего производства, на внутреннем рынке прослеживается тенденция увеличения импорта мяса птицы и колбасных изделий, доля импорта мясных и мясорастительных консервов составляет более 50\% [10]. Импорт продовольственных продуктов, насыщая внутренний рынок, передает информацию, опыт иных стран о современных товарах и технологиях, показывает проблемы отставания мясоперерабатывающих компаний страны в отношении овладения современными технологиями.

Таким образом, актуальной проблемой остается развитие мясной индустрии на основе совершенствования законодательной сферы по поддержке животноводческой отрасли и отечественных предпринимателей. Частью программы развития АПК РК на 2017-2021 гг. являлась Национальная программа «Развитие экспортного потенциала мяса крупного рогатого скота РК» на 2011-2020 гг., а ныне Национальная программа «Развитие мясного животноводства» на 2018-2027 гг. [16]. С целью формирования экспорта мяса правительство страны предоставляет фермерам субсидии на развитие технологической последовательности производства мяса говядины. Вместе со Всемирным банком осуществляется программа развития мясной отрасли РК.

Сложной задачей является гарантирование качества и безопасности мясной продукции. Производство мясной продукции состоит из цепочки большого количества подразделений, начиная с производства кормов и продовольственного сырья до самой продажи, включая используемое оборудование, упаковочные материалы, консерванты, добавки и т. п. Все звенья структуры производства мяса и мясопродуктов взаимосвязаны, что способствует обеспечению качества данных продуктов.

Совершенствование управления компаниями связано с цифровизацией, что требует перемен в порядке планирования, учёта, ревизии, оценки, что сделает информацию гораздо полезней для при- 
нятия быстрых управленческих решений. Таким образом, создание нестандартного способа планирования и учета расходов на качество в нынешнее время является важной задачей экономической деятельности мясопромышленных предприятий.

Рост материального благополучия разнообразил спрос населения, и некоторые потребители перешли на дорогие категории мясных продуктов (казы, шужук, конские сырокопченые колбасы и другие). За последние несколько лет увеличиваются предприятия, производящие по доступной цене вкусные и качественные колбасы, мясные деликатесы, продукции из конины и другие мясные изделия. Они активно используют новейшие технологии, контролируют качество продукции в течении всего производства - от подборки сырья до сбыта конечного продукта. Таким результатам содействовало введение системы менеджмента качества, имеются сертификаты соответствия этим нормам. В республике действуют 275 мясопромышленных предприятий, среди них 50 предприятий ввели систему менеджмента качества ISO [1].

\section{Выводы}

Согласно исследованиям, сложившаяся инвестиционная и технологическая активность предприятий мясной отрасли страны не способствует повышению конкурентоспособности предприятий, из-за нехватки собственных средств, дороговизны модернизации, длительной окупаемости, недостаточной господдержки. В связи с чем, отечественные мясопромышленные компании несут большие потери, что не позволяет им вести расширенное производство.

- Для решения вопросов повышения качества первичного сырья нужно применять методы и новые формы организации подготовки в соответствии с приемлемыми функциональнотехнологическими характеристиками сырья, позволяющие добиваться назначенного качества конечной продукции.

- Совершенствовать законодательную сферу развития мясной промышленности.

- Следует увеличить финансирование для частичного покрытия расходов на покупку кормов и племенного скота, что умень- 
шит себестоимость мяса до $10 \%$ и увеличит доходность до 7\%, а также снизить порог кредитных ставок.

- За счет строительства высокотехнологичных и модернизации действующих предприятий необходимо повысить производственные мощности по убою и переработке скота и производства мясопродуктов.

- Для роста рентабельности и безопасности труда нужно достичь высокого уровня интегрированной автоматизации производственного процесса и уменьшения доли ручного труда.

- За счет оптимального и комплексного применения основного и вторичного сырья мясной промышленности, следует увеличить объёмы переработки. Это улучшит экологическую безопасность и поднимет выработку товарного продукта.

- Нужно модернизировать многоступенчатую логистическую структуру, где должны быть комплексные оптово-распределительные центры, склады, холодильные и морозильные камеры, специализированные автотранспорты для обслуживания предприятий определенной региональной зоны, что позволит уменьшить сроки хранения мясного сырья и сократить расходы на транспорт [2].

Произведенный анализ аграрного сектора показал, что Казахстан страна с открытой экономикой, предельно либеральной внешней торговлей, которая входит в ВТО, ЕАЭС и придерживается рыночных принципов экономики.

Разрешение проблем мясной отрасли позволит заполнить внутренний рынок широким ассортиментом мясных изделий отечественного производства, повысить качество продукции, поднять рентабельность существующих предприятий, создать более высокотехнологичные, направленные на экспорт производства, открыть новые рабочие места.

Повышение конкурентоспособности и эффективности деятельности мясоперерабатывающих предприятий позволит в дальнейшем принять активное участие в международном аграрном рынке. 


\section{Список литературы}

1. Нуркужаев Ж.М., Сигарев М.И. Государственная поддержка в развитии интенсивных технологий в мясном скотоводстве Республики Казахстан. Казахский НИИ экономики АПК и РСТ: Алматы, 2017. $25 \mathrm{c}$.

2. Сапарова Г.К., Султанова Г.Т. Проблемы и перспективы развития аграрного производства в РК в современных условиях. Атырауский университет нефти и газа имени С.Утебаева: Атырау, 2020. 218 с.

3. Агафонов П. В. Импортозамещение за крупными сельскохозяйственными организациями // Экономика сельского хозяйства России. 2017. №4. C. 20-23. https://doi.org/10.32651/2070-0288-2017-4-20-23

4. Ахметжанов Б., Шохор М. О разнице в прибыли при вертикальноинтегрированной и дезинтегрированной форме воспроизводства // Экономист. 2014. № 7. C. 46-52. URL: http://economist-online.ru/ archive/preview/33 (дата обращения 08.12.2020)

5. Кахарманова С.М. Совершенствование системы продовольственного обеспечения в Казахстане // Проблемы Агрорынка. 2020. №2. C. 188-195. https://www.jpra-kazniiapk.kz/jour/article/view/408/357

6. Котляров И.Д. Развитие экспорта российской сельскохозяйственной продукции на основе сетевого сотрудничества в АПК // Экономика сельского хозяйства России. 2018. №2. C.76-84. https://doi. org/10.32651/2070-0288-2018-2-76-84

7. Лисицын А.Б., Небурчилова Н.Ф., Петрунина И.В. Современное состояние и перспективы развития мясной отрасли АПК // Проблемы прогнозирования. 2016. №1 (154). С. 50-61. https://ecfor.ru/ publication/sostoyanie-perspektivy-razvitiya-myasnoj-otrasli-apk/

8. Миндлин Ю.Б. Партнерство малого и крупного агробизнеса как условие устойчивого развития отечественного АПК // Экономика сельскохозяйственных и перерабатывающих предприятий. 2020. №4. C. 49-52. http://www.eshpp.ru/abstract/2020-04_abst.htm

9. Плотников В.А., Сулейманова М.В. Анализ моделей обеспечения национальной продовольственной безопасности // Экономика сельскохозяйственных и перерабатывающих предприятий. 2019. №5. C. 7-12. http://www.eshpp.ru/j2019-5.html 
10. Сурганов В. Фермерские ведомости. 2019. https://kazvedomosti.kz/ article/myasnoj-peredel (дата обращения: 11.12.2020).

11. Казахстан: 1991-2002 годы. Агентство РК по статистике. Алматы, 2002. C. 294.

12. Статистическое обозрение Казахстана. Информационный бюллетень Казахстана. 2001. №3. С. 23.

13. Статистический сборник РК. 2019. http://www.stat.gov.kz (дата обращения: 12.12.2020).

14. Доклад министра сельского хозяйства $\mathrm{PK}$ «О текущем состоянии животноводства». https://primeminister.kz/ru/news/v-sektorezhivotnovodstva-sohranyaetsya-ustoychivyy-rost-na-urovne-4-mshrk-2643521 (дата обращения: 15.12.2020).

15. Льготный кредитный продукт «Сыбага». https://online.zakon.kz/ Document/?doc_id=31272794 (дата обращения: 16.12.2020).

16. Национальная программа «Развитие мясного животноводства» на 2018-2027 гг. https://meatunion.kz/images/nacionalnayaprogramma.pdf (дата обращения: 16.12.2020).

17. План нации - 100 шагов по реализации пяти институциональных peформ. https://online.zakon.kz/document/?doc_id=31977084 (дата обращения: 16.12.2020).

18. Приказ Министра национальной экономики Республики Казахстан от 9 декабря 2016 года № 503 «Об утверждении научно обоснованных физиологических норм потребления продуктов питания». http:// adilet.zan.kz/rus/docs/V1600014674 (дата обращения: 17.12.2020).

19. Nassyrova A., Yessymkhanova Z., Issayeva B., Omarkhanova Zh., Niyazbekova Sh., Berzhanova A., Murtuzalieva S., Kunanbayeva K. Kazakhstan meat industry analysis: import substitution, delivery and statistics // Entrepreneurship and sustainability issues. 2020, vol. 8, no. 1, pp. 640-655. https://doi.org/10.9770/jesi.2020.8.1(44)

20. Nassyrova A., Niyazbekova Sh., Ilyas A., Zhanabayeva Zh., Khassenova K., Tlessova E. Role of the Industry Import Substitution Strategy in the Country Economy // Proceedings of the IV International Scientific and Practical Conference 'Anthropogenic Transformation of Geospace: Nature, Economy, Society’ (ATG 2019). Atlantis Press SARL Publ., pp. 23-25. https://doi.org/10.2991/aer.k.200202.005 
21. Nurgabylov M.N., Baymagambetova Z.A., Nassyrova A.M., Kuangalieva T.K., Akimova B.Zh. Basis for technological innovation in the economic development of agriculture // Известия НАН РК. Серия общественных и гуманитарных наук, 2019, vol. 4, no. 326, pp. 176-179. https://doi. org/10.32014/2019.2224-5294.153

22. Saginova S., Doskaliyeva B., Saparova G., Tleuzhanova M., Kassenova A., Temirbulatov A. Problems of Ensuring the Food Security // Journal of Advanced Research in Law and Economics, 2017, vol. 8, no. 4 (26), pp. 1295-1300. https://journals.aserspublishing.eu/jarle/article/view/1535

23. Saparova G.K., Saginova S.A., Sultanova G.T. Role of Boundary Regions in the Development of Agricultural Production and Ensuring Food Security of the Kazakhstan $/ / 25^{\text {th }}$ EBES conf. Berlin, 2018, vol. 3, pp. 1622-1626.

\section{References}

1. Nurkuzhaev Zh.M., Sigarev M.I. Gosudarstvennaya podderzhka v razvitii intensivnykh tekhnologiy v myasnom skotovodstve Respubliki Kazakhstan [State support in the development of intensive technologies in beef cattle breeding of the Republic of Kazakhstan]. Kazakh Research Institute of Economics of Agroindustrial Complex and PCT: Almaty, 2017. 25 p.

2. Saparova G.K., Sultanova G.T. Problemy i perspektivy razvitiya agrarnogo proizvodstva $v$ RK v sovremennykh usloviyakh [Problems and prospects for the development of agricultural production in the Republic of Kazakhstan in modern conditions]. Atyrau University of Oil and Gas named after S. Utebayev: Atyrau, 2020. 218 p.

3. Agafonov P.V. Importozameshchenie za krupnymi sel'skokhozyaystvennymi organizatsiyami [Import substitution for large agricultural organizations]. Ekonomika selskogo khozyaystva Rossii, 2017, no. 4, pp. 20-23. https://doi.org/10.32651/2070-0288-2017-4-20-23

4. Akhmetzhanov B., Shokhor M. O raznitse v pribyli pri vertikal'no-integrirovannoy i dezintegrirovannoy forme vosproizvodstva [On the difference in profit in the case of vertically integrated and disintegrated forms of reproduction]. Economist, 2014, no. 7, pp. 46-52. http://economist-online.ru/archive/preview/33 
5. Kakharmanova S.M. Sovershenstvovanie sistemy prodovol'stvennogo obespecheniya v Kazakhstane [Improving the food supply system in Kazakhstan]. Problemy Agrorynka, 2020, no. 2, pp. 188-195. https://www. jpra-kazniiapk.kz/jour/article/view/408/357

6. Kotlyarov I.D. Razvitie eksporta rossiyskoy sel'skokhozyaystvennoy produktsii na osnove setevogo sotrudnichestva v APK [Development of the export of Russian agricultural products on the basis of network cooperation in the agro-industrial complex]. Ekonomika selskogo khozyaystva Rossii, 2018, no. 2, pp. 76-84. https://doi.org/10.32651/2070-0288-2018-2-76-84

7. Lisitsyn A.B., Neburchilova N.F., Petrunina I.V. Sovremennoe sostoyanie i perspektivy razvitiya myasnoy otrasli APK [The current state and development prospects of the meat industry of the agro-industrial complex]. Problemy prognozirovaniya, 2016, no. 1 (154), pp. 50-61. https://ecfor. $\mathrm{ru} /$ publication/sostoyanie-perspektivy-razvitiya-myasnoj-otrasli-apk/

8. Mindlin Yu.B. Partnerstvo malogo i krupnogo agrobiznesa kak uslovie ustoychivogo razvitiya otechestvennogo APK [Partnership of small and large agribusiness as a condition for sustainable development of the domestic agro-industrial complex]. Ekonomika sel'skokhozyay-stvennykh $i$ pererabatyvayushchikh predpriyatiy, 2020, no. 4, pp. 49-52. http://www. eshpp.ru/abstract/2020-04_abst.htm

9. Plotnikov V.A., Suleymanova M.V. Analiz modeley obespecheniya natsional'noy prodovol'stvennoy bezopasnosti [Analysis of models for ensuring national food security]. Ekonomika sel'skokhozyaystvennykh i pererabatyvayushchikh predpriyatiy [Economy of agricultural and processing enterprises], 2019, no. 5, pp. 7-12. http://www.eshpp.ru/j2019-5.html

10. Surganov V. Farmerskie vedomosti. 2019. https://kazvedomosti.kz/article/myasnoj-peredel

11. Kazakhstan: 1991-2002. Statistics Agency of the Republic of Kazakhstan. Almaty, 2002, p. 294.

12. Statistical Review of Kazakhstan. Information bulletin of Kazakhstan, 2001, no. 3, p. 23.

13. Statistical collection of the RK, 2019. http://www.stat.gov.kz

14. Report of the Minister of Agriculture of the Republic of Kazakhstan "On the current state of animal husbandry". https://primeminister.kz/ru/ 
news/v-sektore-zhivotnovodstva-sohranyaetsya-ustoychivyy-rost-na-ur ovne-4-msh-rk-2643521

15.Preferential loan product "Sybaga". https://online.zakon.kz/Document/?doc_id=31272794

16. National program "Development of beef cattle breeding” for 2018-2027. https://meatunion.kz/images/nacionalnayaprogramma.pdf

17. Plan of the Nation - 100 Steps to Implement Five Institutional Reforms. https://online.zakon.kz/document/?doc_id=31977084

18. Order of the Minister of National Economy of the Republic of Kazakhstan dated December 9, 2016 No. 503 "On the approval of scientifically grounded physiological norms of food consumption." http://adilet.zan. $\mathrm{kz} / \mathrm{rus} / \mathrm{docs} / \mathrm{V} 1600014674$

19. Nassyrova A., Yessymkhanova Z., Issayeva B., Omarkhanova Zh., Ni-yazbekova Sh., Berzhanova A., Murtuzalieva S., Kunanbayeva K. Kazakhstan meat industry analysis: import substitution, delivery and statistics. Entrepreneurship and sustainability issues. 2020, vol. 8, no. 1, pp. 640655. https://doi.org/10.9770/jesi.2020.8.1(44)

20. Nassyrova A., Niyazbekova Sh., Ilyas A., Zhanabayeva Zh., Khassenova K., Tlessova E. Role of the Industry Import Substitution Strategy in the Country Economy. Proceedings of the IV International Scientific and Practical Conference 'Anthropogenic Transformation of Geospace: Nature, Economy, Society '(ATG 2019). Atlantis Press SARL Publ., Pp. 23-25. https://doi.org/10.2991/aer.k.200202.005

21. Nurgabylov M.N., Baymagambetova Z.A., Nassyrova A.M., Kuangalieva T.K., Akimova B.Zh. Basis for technological innovation in the economic development of agriculture. Bulletin of the National academy of sciences of the republic of Kazakhstan. Social Sciences and Humanities Series, 2019, vol. 4, no. 326, pp. 176-179. https://doi.org/10.32014/2019.22245294.153

22. Saginova S., Doskaliyeva B., Saparova G., Tleuzhanova M., Kassenova A., Temirbulatov A. Problems of Ensuring the Food Security. Journal of Advanced Research in Law and Economics, 2017, vol. 8, no. 4 (26), pp. 1295-1300. https://journals.aserspublishing.eu/jarle/article/ view/1535 
23. Saparova G.K., Saginova S.A., Sultanova G.T. Role of Boundary Regions in the Development of Agricultural Production and Ensuring Food Security of the Kazakhstan. 25th EBES conf. Berlin, 2018, vol. 3, pp. 1622-1626.

\section{ДАННЫЕ ОБ АВТОРАХ}

Сапарова Гульнар Каримовна, профессор кафедры «Экономика и менеджмент», доктор экономических наук AO «Финансовая Академия» ул. Ш. Валиханова, 11, г. Нур-Султан, 010000, Казахстан Saparova_g.k@mail.ru

Касенова Асия Жандарбековна, доцент кафедры «Экономика и менеджмент», кандидат экономических наук АO «Финансовая Академия»

ул. Ш. Валиханова, 11, г. Нур-Султан, 010000, Казахстан Kasenova_a@bk.ru

Насырова Анар Мирамбековна, докторант $\mathrm{PhD}$

АО «Финансовая Академия»

ул. Ш. Валиханова, 11, г. Нур-Султан, 010000, Казахстан Anar_nassyrova@mail.ru

Сулейманов Рустам Эдуардович, докторант $\mathrm{PhD}$ АО «Финансовая Академия» ул. Ш. Валиханова, 11, г. Нур-Султан, 010000, Казахстан Suleimanov_r@mail.ru

\section{DATA ABOUT THE AUTHORS}

Saparova Gulnar Karimovna, Professor of the Department of Economics and Management, Doctor of Economics

Financial Academy

11, Valikhanov Str., Nur-Sultan, 010000, Kazakhstan

Saparova_g.k@mail.ru

ORCID: 0000-0003-3414-1787 
Kassenova Asiya Zhandarbekovna, Associate Professor of the Department "Economics and management", Candidate of Economic Sciences

Financial Academy

11, Valikhanov Str., Nur-Sultan, 010000, Kazakhstan

Kasenova_a@bk.ru

ORCID: 0000-0002-0853-6235

Nassyrova Anar Mirambekovna, PhD student

Financial Academy

11, Valikhanov Str., Nur-Sultan, 010000, Kazakhstan

Anar_nassyrova@mail.ru

ORCID: 0000-0002-3847-3933

Suleimanov Rustam Eduardovich, $\mathrm{PhD}$ candidate

Financial Academy

11, Valikhanov Str., Nur-Sultan, 010000, Kazakhstan

Suleimanov_r@mail.ru

ORCID: 0000-0003-2878-9253 